\title{
Evaluation of Tensile Strength and Slurry Erosive Behaviour of Jute Reinforced Natural Rubber Based Flexible Composite
}

\author{
Vishwas Mahesh ${ }^{1,2^{*}}$, Sharnappa Joladarashi ${ }^{1}$, Satyabodh M. Kulkarni ${ }^{1}$ \\ ${ }^{1}$ Department of Mechanical Engineering, National Institute of Technology Karnataka, Surathkal, Mangaluru 575025, India \\ ${ }^{2}$ Department of Industrial Engineering and Management, Siddaganga Institute of Technology, Tumakuru 572103, India
}

Corresponding Author Email: vishwasm@sit.ac.in

https://doi.org/10.18280/rcma.300204

Received: 23 December 2019

Accepted: 16 February 2020

\section{Keywords:}

jute, rubber, tensile characterization, slurry erosion characterization, composite flexible

\begin{abstract}
Polymer based natural fiber reinforced composites are finding their applications in almost all fields of engineering. Flexible composites are different class of composite materials finding their usage in secondary structural application such as sacrificial structures like claddings. Mechanical and tribological characterization of the newly developed composites becomes important prior to using them in any engineering application. The present study concentrates on evaluating the tensile and slurry erosive behaviour of flexible composite manufactured by reinforcing naturally available jute fiber in the form of woven fabric in the naturally available sun dried rubber sheets (NR) using compression moulding technique. ASTM D412 standard is used to evaluate the tensile properties of the proposed flexible composite and the NR sheets. The slurry erosive behaviour is assessed using Ducom slurry erosion testing machine. The results reveal that reinforcing jute with natural rubber enhances the tensile strength compared to natural rubber sheet and the wear of the proposed flexible composite is minimal due to inclusion of natural rubber which is elastic in nature.
\end{abstract}

\section{INTRODUCTION}

Composite materials are well known for their superior properties compared to metals and alloys. Among all, polymer matrix composites (PMC) are widely used due to ease of fabrication, low cost and low density. Engineers in almost all industries are using synthetic fibers to minimize the component weight $[1,2]$, but owing to environmental and energy concerns, researchers are losing interest in synthetic fibers $[3,4]$. The natural fibers are slowly taking over the synthetic fibers in almost all industries. The automotive industry has already started using the components made by natural fibers, especially in their interior parts $[5,6]$.

A growing environmental awareness across the world has aroused interest in research and development of environmentally friendly and sustainable materials. Cellulosic materials, namely, plant-based natural fibers such as flax, hemp, bamboo, and wood, have low densities, are biodegradable, and inexpensive, and they have relatively high stiffness and less wear and abrasion to material partners. If such cellulosic materials are used as reinforcements of biomass-derived plastics, this material would be a quite suitable for building a sustainable society. In the composites reinforcement, the natural fibers use is growing, primarily because of environmental and economic concerns. Natural fibers mostly used are straw, flax, hemp and jute. Compared to hemp fiber, jute has the advantage of being easy to weave.

Composites are subjected to different types of loading during their service which makes it very essential to assess their behaviour when subjected to such loading prior to finalizing their usage in any proposed engineering application.
Composites made up of jute fiber in combination with both synthetic and natural resin has been assessed for their behaviour by various researchers [7-13] for their mechanical properties. The behaviour of creep of alkali treated jute/green composite where various loadings are incorporated at different environmental temperatures was studied which showed an increase in storage modulus and glass transition temperature [14].

The effect in using natural fibre as reinforcement material in HPMC was discussed by Vimal et al. [15]. The jute fibres were modified chemically by treating them with succinic anhydride and phthalic anhydride at concentrations of $5 \%$, $10 \%, 20 \%$ and $30 \%$ using retting method. Among these, the composite made with phthalicylated fibre with $20 \%$ concentration has shown good flexural properties when compared to the other materials.

Green eco-design of automotive components by making use of natural jute fibre composite was discussed by El-Sayed et al. [16-18]. Analysis on the mechanical and thermal properties of jute and glass fibre reinforcement epoxy hybrid composites was studied by Braga and Magalhaes [19] and concluded that the addition of jute fibre and glass fibre in epoxy increases the impact energy, tensile strength and flexural strength of the composite.

To overcome the problem involved in wear of structural components, the need for newer materials is growing day by day. Fiber reinforced polymer-based composites find the top priority in the rapidly growing class of material due to the enormous advantage they provide and are being used in a variety of engineering applications. Tribological properties are important for polymer-based composites which enforced 
many researchers to concentrate on studying and improving the friction and wear behavior of such composites.

The relative motion between the surface and the other surface which is in contact with it results in loss of material causing damage to the surface. This is termed as wear. Different types of wear such as adhesion, abrasion, erosion, fatigue, and fretting are observed in practice.

The study carried out by Manoj et al. [20] showed that the slurry erosive resistance of $\mathrm{Fe}-\mathrm{TiC}$ composite can be improved by adding $\mathrm{TiC}$ in $\mathrm{Fe}$ matrix. The comparative study on erosive behaviour of fly ash reinforced Al-Cu alloy and unreinforced alloy was carried out by Mahendra and Radhakrishna [21] and found that addition of flyash enhances the erosion resistance. The erosive behaviour of Al-SiC composite was studied by Ramachandra and Radhakrishna [22] and concluded that increase in the $\mathrm{SiC}$ resulted in enhanced resistance to erosion. The influence of erodent characteristics on erosion resistance of titanium was studied by Lindgren and Perolainen [23]. The slurry erosive behaviour of metal matrix coatings was studied by Farahmand et al. [24]. The slurry erosive wear behaviour of $\mathrm{SiC}$ ceramic foam/epoxy co-continuous phase composite was studied by Ren et al. [25]. Slurry erosive behaviour of basalt reinforced low density polyethylene was studied by Akinci et al. [26].

Many researchers have studied the slurry erosive wear behaviour of metals, alloys and in the field of composites, metal matrix composites are concentrated. Since nowadays, the polymer matrix composites are replacing the metals, alloys and metal matrix composites owing to various advantages like cost and weight, the study of erosive behaviour of polymer matrix composites under slurry environment is essential [27].

Flexible polymeric based composites are finding their application in material handling, material transportation systems and claddings with various polymer displaying diverse tribological properties. It is worth noting that neat polymers are seldom used for applications involving wear. Study of abrasive wear in material handling systems, material transportation systems and claddings are gaining importance. Bidirectional fabrics have emerged as a solution for fulfilling the demand for newer materials having better performance and processing. Enhancing the hardness and stiffness of the material to get improved wear resistance of polymeric materials is a conventional approach. The tribological properties of the composites are influenced to a greater extent by the matrix material used. Nature has provided us with plenty of materials that can address the various issue. For example, the hardness incorporated in nails and teeth helps us in grinding, digging and tearing purpose. The feet which has soft pads helps in reducing the wear and tear during transportation. On these grounds, it becomes interesting to explore the use of elastomer for Tribo applications. Elastomers have a narrow range of operating temperature within which they can be used as wear resistant materials.

Replacement of steel with rubber or coating the steel with rubber will reduce the wear rate. The natural rubber apart from offering wear resistance also offers advantage such as tear and impact resistance. Different types of wear mechanisms have been proposed by various researchers pertaining to rubber. When rubber is abraded unidirectionally, the characteristic surface pattern consisting of a series of periodic parallel ridges lying perpendicular to the sliding direction, looking like a wind-wrought pattern on the sand, often referred to as abrasion pattern is formed. The ridges forming on the surface of the rubber when it is abraded is indicative of wear mechanism. Ridges were generated by coalescence of particles, sequentially through the formation of ribs, rings, and ruffles. The wear pattern was also discussed. In spite of the obvious possibility of utilization of wear resistant application, studies on tribological properties of jute reinforced natural rubber flexible composite have not received due attention

Elastomers provide cutting edge advantage over other wear resistant materials in terms of resilience, ease of fabrication, corrosion resistance, toughness, vibration damping capability and so on. Natural rubbers have excellent resistance to erosion and abrasion when hydrocarbon and weathering resistance are not essential. Elastomers find their application in hoses, pipe linings, hose bends, side liners and pump casing [28]. There are various parameters that affect erosion rate during slurry pot testing like particle velocity, abrasive concentration, particle size and property of material [29, 30].

Application of composite materials in slurry environment is increasing rapidly in the field of engineering over few decades. The significance of slurry erosion is increasing nowadays due to increase in number of slurry handling processes. Though the study in slurry erosion is widely done, still it is of greater importance for any composite due to its complex nature [27].

Lack of study is found in the area of completely green composite, especially with a combination of jute and rubber. In this study, the tensile properties of jute-rubber composite are studied and compared with that of pure rubber. Also, the slurry erosion behaviour of the proposed composite material is studied to confirm its suitability to applications that may involve erosion due to slurry. Thus, the present study deals with assessing the tensile strength and wear resistance in slurry environment of the jute reinforced flexible composite.

\section{EXPERIMENTAL}

\subsection{Materials}

Naturally available jute is used as a fiber in woven fabric form and the sun-dried natural rubber sheets are used as matrix. Both jute and natural rubber sheets were procured from local suppliers. The jute fabric used has a GSM of 350. The weight percentage of fiber and rubber are $30 \%$ and $70 \%$ respectively. The jute fabric and the rubber sheet used in fabrication are shown in Figure 1. The properties of the jute fiber and the NR sheet used in the present study are tabulated in Table 1 and Table 2 respectively.

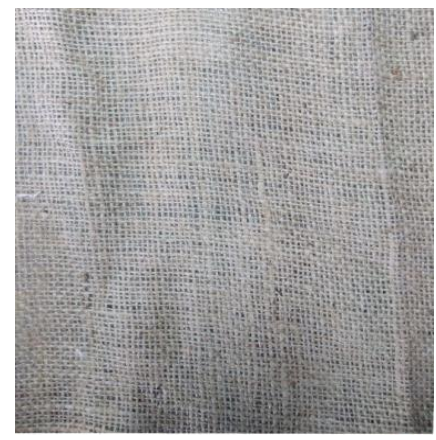

(a)

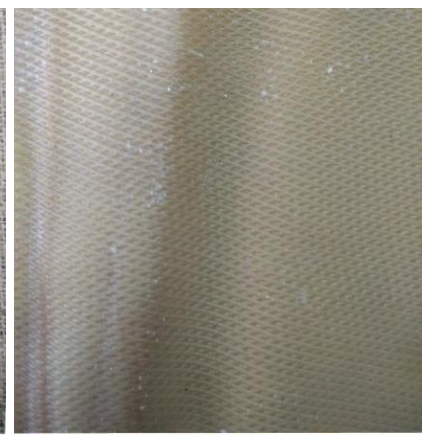

(b)
Figure 1. (a) Jute and (b) rubber sheets used to prepare composite 
Table 1. Properties of jute fiber

\begin{tabular}{ccccc}
\hline Material & Tensile Strength (MPa) & Diameter $(\boldsymbol{\mu m})$ & Density $\left(\mathbf{K g} / \mathbf{m}^{3}\right)$ & Youngs Modulus $(\mathbf{G P a})$ \\
\hline Jute & 700 & 180 & 1450 & 30 \\
\hline
\end{tabular}

Table 2. Properties of NR sheet

\begin{tabular}{ccccc}
\hline Material & Yield stress (MPa) & Ultimate stress (Mpa) & Density (Kg/m $\left.\mathbf{m}^{\mathbf{3}}\right)$ & Youngs Modulus (Mpa) \\
\hline Natural Rubber & 0.05 & 0.05 & 987.18 & 0.45 \\
\hline
\end{tabular}

\subsection{Fabrication of proposed flexible composite}

Compression moulding method is selected to manufacture the proposed flexible composite. The jute fabric and NR sheets are cut into $300 \mathrm{~mm} \times 300 \mathrm{~mm}$ dimension and arranged as represented in Figure 2.

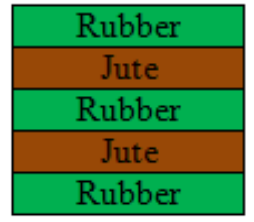

Figure 2. Schematic representation of composite

Two aluminium plates covered with Teflon sheet are taken and the arranged stacking sequence of composite is placed in between the two plates as shown in Figure 3(a). Releasing agent is applied to the plates to facilitate easy removal of the laminate after curing. The cured laminates are shown in Figure 3(b).

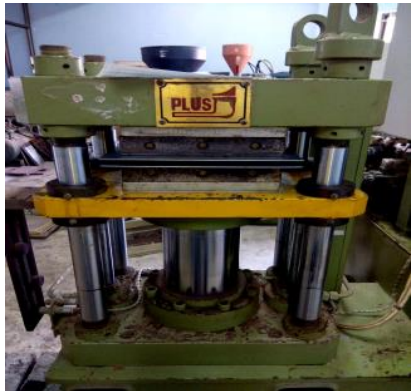

(a)

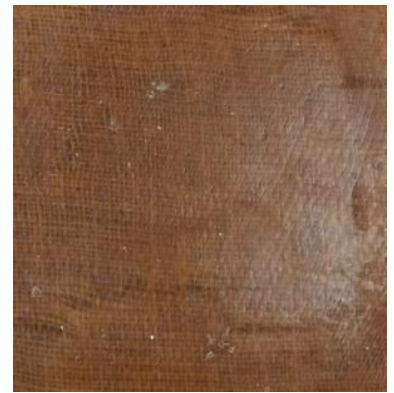

(b)
Figure 3. Mould placed in the compression moulding machine

The steps used in fabrication of composite are given below:

Step 1: The temperature was set to 140 degree Celsius in the compression moulding machine and pressure was maintained at zero $\mathrm{Kg} / \mathrm{cm}^{2}$.

Step 2: Once the set temperature of 140 degree celcius is reached, the pressure was raised to $50 \mathrm{Kg} / \mathrm{cm}^{2}$ and the situation was kept for 20 mins.

Step 3: After 20 mins, the temperature was turned off and the pressure was maintained for another 1.5 hours

Step 4: The mould was removed from the compression moulding machine and then the composite was removed from the moulds. The obtained composite laminate is as shown in Figure 3(b).

\subsection{Tensile characterization of composites}

The specimens required for the tensile testing of rubber were cut from the rubber sheet and composite were cut from the manufactured composite laminate based on ASTM D412 as shown in Figure 4 and tensile properties of the composites were evaluated using the universal testing machine (UTM), Tinius Olsen H75KS make with cross head speed of 500 $\mathrm{mm} / \mathrm{min}$ and compared with pure rubber.
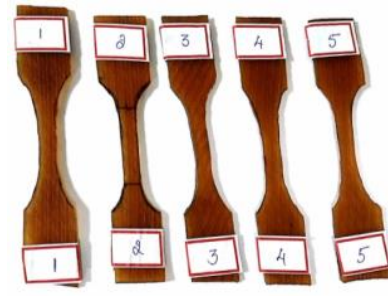

(a)

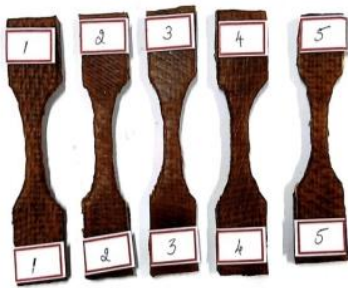

(b)
Figure 4. Tensile test specimens (a) rubber and (b) juterubber before testing

\subsection{Slurry erosion of composite}

The jute-rubber composites manufactured were subjected to slurry erosion test using slurry pot method using the Ducom slurry erosion tester as shown in Figure 5 (a). The specimen is cut into a rectangular shape with dimension of $76 \mathrm{~mm} \times 25 \mathrm{~mm}$ $\mathrm{x} 6 \mathrm{~mm}$ as per the specification provided by the supplier. The slurry is prepared by adding 15 gms of fly ash with 50 gms of sand to 1 litre of water and the mixture is slurry at a stirred well. The test was conducted at room temperature. The pre weighed samples were fixed into the specimen holder. The slurry pot is fixed in its position and the specimen was rotated inside the speed of $1500 \mathrm{rpm}$ for 1 hour. Five such specimens were subjected to testing and each time new slurry concentration is prepared. The wear of the samples was measured as a function of weight loss. The samples after test were cleaned using acetone. Since the composite is made of only jute and rubber, it has a tendency to absorb water. Hence, the specimen after test was dried in atmospheric conditions for about a week and then the weight was checked using electronic weighing machine. The sand used for the slurry erosion test and the slurry prepared are shown in Figure 5(b) and Figure 5 (c) respectively. The initial and final specimen subjected to slurry erosion test is shown in Figure 6.

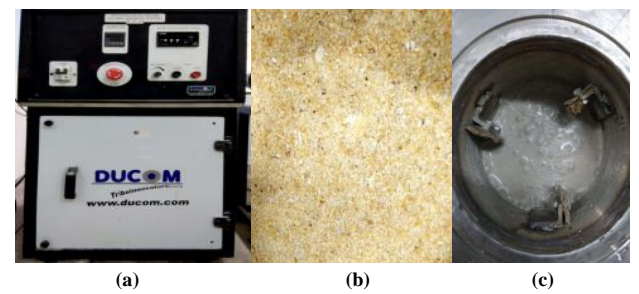

Figure 5. (a) Slurry erosion tester, (b) sand used as abrasive and (c) slurry prepared 


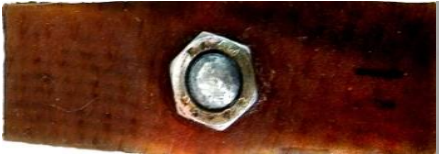

(a)

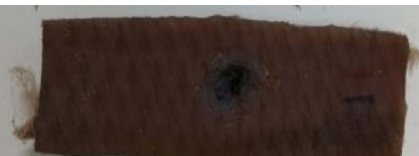

(b)
Figure 6. Specimen (a) before and (b) after slurry erosion test

\section{RESULTS AND DISCUSSIONS}

\subsection{Tensile testing}

The pure rubber and the composite were subjected to tensile test in a computer controlled UTM. Five specimens of each pure rubber and jute-rubber were tested according to ASTM standards and their average is taken in case of experimental data. The test was conducted at room temperature. The load required to completely break the specimen is taken as the break force. The results obtained from the tensile test of pure rubber and Jute-Rubber composite is tabulated in Table 3. The typical failure modes of rubber and jute-rubber composites are presented in Figure 7.

Table 3. Tensile test results

\begin{tabular}{cccc}
\hline Specimen & $\begin{array}{c}\text { Ultimate } \\
\text { Force (N) }\end{array}$ & $\begin{array}{c}\text { Break } \\
\text { Force (N) }\end{array}$ & $\begin{array}{c}\text { Modulus } \\
(\mathbf{M P a})\end{array}$ \\
\hline Pure Rubber & 7 & 3.33 & 0.45 \\
Jute-Rubber Composite & 120 & 7.15 & 4.934 \\
\hline
\end{tabular}

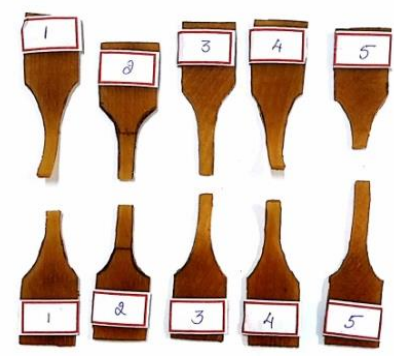

(a)

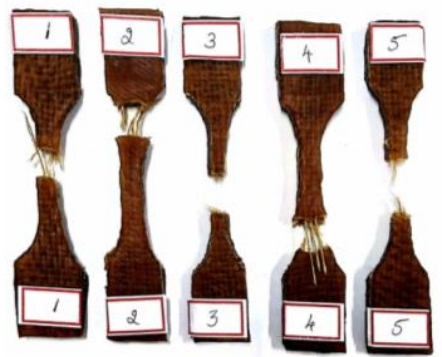

(b)
Figure 7. Specimen of (a) rubber and (b) jute-rubber after experimental tensile test

It can be concluded by comparing the results of rubber and jute-rubber composite that the force required to completely break the specimen is 2.15 times more for composite than that of rubber. This indicates that the addition of jute as a fiber enhances the tensile strength of the composite. Also it can be seen that the modulus of composites is enhanced significantly by 11.21 times compared to that of rubber. This is mainly because of addition of jute as a fiber which incorporated stiffness in the composite. Thus addition of jute to rubber significantly enhances the tensile properties.

\subsection{Slurry erosion test}

The result pertaining to mass loss during slurry erosion testing of the jute-rubber flexible composite is tabulated in Table 4.

From the results of slurry erosion test and observing the specimen, it can be concluded that there is a weigh loss of 0.275 gms which is negligible, but the composite absorbs water content form the slurry and takes days together to dry. And also the bonding between jute and the rubber is affected due to its contact with water. Hence this composite, in its present configuration of materials may not be a suitable candidate for the applications involving erosion due to slurry. If the drawbacks identified during slurry erosion test can be addressed, the proposed composite can be of significant use due to its complete biodegradability.

Table 4. Weight loss after slurry erosion test

\begin{tabular}{cccc}
\hline Specimen & $\begin{array}{c}\text { Initial } \\
\text { Mass }(\mathbf{g m s})\end{array}$ & $\begin{array}{c}\text { Final Mass } \\
(\mathbf{g m s})\end{array}$ & $\begin{array}{c}\text { Weight } \\
\text { loss }(\mathbf{g m s})\end{array}$ \\
\hline Jute-Rubber Composite & 12.71 & 12.435 & 0.275 \\
\hline
\end{tabular}

\section{CONCLUSIONS}

In the present work, an attempt has been made to develop a low cost, completely green composite concentrating on its tensile and erosion properties. The following conclusions are drawn from the present study:

- $\quad$ Force required to completely break the specimen is 2.15 times more for composite than that of rubber. This indicates that the addition of jute as a fiber enhances the tensile strength of the composite.

- Modulus of composites is enhanced significantly by 11.21 times compared to that of rubber. This is mainly because of addition of jute as a fiber which incorporated stiffness in the composite. Thus addition of jute to rubber significantly enhances the tensile properties.

- Though the wear due to erosion is negligible, the composite absorbs water content form the slurry and takes days together to dry which is undesirable.

- Bonding between jute and the rubber is affected due to its contact with water. Hence this composite, in its present configuration of materials may not be a suitable candidate for the applications involving erosion due to slurry.

- Hence taking forward the positives from the tensile study, it can be concluded that jute rubber composite can be a potential green composite provided the negatives found during the slurry erosion test is addressed.

\section{ACKNOWLEDGEMENT}

The authors would like to thank the Composite Research Centre and Material Characterization Laboratory, Department of Mechanical Engineering, National Institute of Technology Karnataka (NITK), Surathkal, Mangaluru, India for providing the fabrication and testing facilities. Authors also extend their gratitude towards Manjunath Rubbers, Baikampady, Mangaluru, Karnataka, India for providing natural rubber sheets. One of the author, Mr. Vishwas Mahesh would like to acknowledge the management of Siddaganga Institute of Technology, Tumakuru for providing deputing him to pursue his Ph.D at NITK Surathkal and also he would like to thank All India Council for Tecnical Education, Governament of India for scholarship to pursue his Ph.D under Quality Improvement Programme.

\section{REFERENCES}

[1] Kling, S., Czigány, T. (2014). Damage detection and self-repair in hollow glass fiber fabric-reinforced epoxy 
composites via fiber filling. Composite Science and Technology, 99: 82-88. http://dx.doi.org/10.1016/j.compscitech.2014.05.020

[2] Wang, ZQ., Xu, L.D., Sun, X.Y., Shi, M.F., Liu, J.B. (2017). Fatigue behavior of glass-fiber-reinforced epoxy composites embedded with shape memory alloy wires. Composite $\quad$ Structures, 178: 311-319. http://dx.doi.org/10.1016/j.compstruct.2017.07.027

[3] Wambua, P., Ivens, J., Verpoest, I. (2003). Natural fibres: Can they replace glass in fibre reinforced plastics? Composite Science and Technology, 63(9): 1259-1264. http://dx.doi.org/10.1016/S0266-3538(03)00096-4

[4] Monteiro, S.N., Lopes, F.P.D., Ferreira, A.S., Nascimento, D.C.O. (2009). Natural-fiber polymermatrix composites: Cheaper, tougher, and environmentally friendly. The Journal of the Minerals, Metals and Materials Society, 61(1): 17-22. http://dx.doi.org/10.1007/s11837-009-0004-z

[5] Grcaeraj, P.P., Venkatachalam, G. (2015). Investigations into tensile strength of jute fiber reinforced hybrid polymer matrix composites. Engineering Review, 35(3): 275-281

[6] Nabila, S., Juwono, A.L., Roseno, S. (2017). Effect of weight fractions of jute fiber on tensile strength and deflection temperature of jute fiber/polypropylene composites. IOP Conference series: Material Science and Engineeirng, $\quad 196(1)$ : 012029. http://dx.doi.org/10.1088/1757-899X/196/1/012029

[7] Holbery, J., Houston, D. (2006). Natural-fiber-reinforced polymer composites in automotive applications. The Journal of the Minerals, Metals and Materials Society, 58(11): 80-86. http://dx.doi.org/10.1007/s11837-006$0234-2$

[8] Thomas, B.D.S., Paul, S.A., Pothan, A. (2011). Natural fibres: Structure, properties and applications. In I. K. Susheel Kalia., Kaith, BS. (eds) Cellulose Fibers: Bioand Nano-Polymer Composites. Springer, Berlin, Heidelberg.

[9] Mahesh, V., Joladarashi, S., Kulkarni, S.M. (2019). Development and mechanical characterization of novel polymer-based flexible composite and optimization of stacking sequences using VIKOR and PSI techniques. Journal of Thermoplastic Composite Materials, 1-23. https://doi.org/10.1177/0892705719864619

[10] Mahesh, V., Joladarashi, S., Kulkarni, S.M. (2019). An experimental investigation on low-velocity impact response of novel jute/ rubber flexible bio-composite. Composite $\quad$ Structures, 225 : 111190. https://doi.org/10.1016/j.compstruct.2019.111190

[11] Mahesh, V., Joladarashi, S., Kulkarni, S.M. (2019). Physio-mechanical and wear properties of novel jute reinforced natural rubber based flexible composite Physio-mechanical and wear properties of novel jute reinforced natural rubber based flexible composite. Materials Research Express, 6(5): 055503. https://doi.org/10.1088/2053-1591/ab0164

[12] Mahesh, V., Joladarashi, S., Kulkarni, S.M. (2018). Experimental investigation on slurry erosive behaviour of biodegradable flexible composite and optimization of parameters usi ng Taguchi's approach. Revue des Composites et des Materiaux Avances, 28(3): 345-355. https://doi.org/10.3166/RCMA.28.345-355

[13] Mahesh, V., Joladarashi, S., Kulkarni, S.M. (2019). An experimental study on adhesion, flexibility, interlaminar shear strength, and damage mechanism of jute/rubberbased flexible 'green' composite. Journal of Thermoplastic Composite Materials, 1-28. https://doi.org/10.1177/0892705719882074

[14] Jabbar, A., Militký, J., Madhukar Kale, B., Rwawiire, S., Nawab, Y., Baheti, V. (2016). Modeling and analysis of the creep behavior of jute/green epoxy composites incorporated with chemically treated pulverized nano/micro jute fibers. Industrial Crops and Products, 84 : 230-240. http://dx.doi.org/10.1016/j.indcrop.2015.12.052

[15] Vimal, R., Subramanian, K., Aswin, C., Logeswaran, V., Ramesh, M. (2015). Comparisonal study of succinylation and phthalicylation of jute fibres: Study of mechanical properties of modified fibre reinforced epoxy composites. Materials Today Proceedings, 2(4-5): 2918-2927. http://dx.doi.org/10.1016/j.matpr.2015.07.254

[16] El-Sayed, A.A., El-Sherbiny, M.G., Abo-El-Ezz, A.S., Aggag, G.A. (1995). Friction and wear properties of polymeric composite materials for bearing applications. Wear, 184(1): 45-53. https://doi.org/10.1016/00431648(94)06546-2

[17] Symington, M.C., Banks, W.M., West, O.D., Pethrick, R.A. (2009). Tensile testing of cellulose based natural fibers for structural composite applications. Journal of Composite Materials, 43(9): 1083-1108. http://dx.doi.org/10.1177/0021998308097740

[18] Alves, C., Ferraro, P.M.C., Silva, A.J., Reis, L.G., Freitas, M., Rodrigues, L.B., Alves, D.E. (2010). Ecodesign of automotive components making use of natural jute fiber composites. Journal of Cleaner Production, 18(4): 313327. http://dx.doi.org/10.1016/j.jclepro.2009.10.022

[19] Braga, R.A., Magalhaes, P.A.A. (2015). Analysis of the mechanical and thermal properties of jute and glass fiber as reinforcement epoxy hybrid composites. Materials Science and Engineering: C, 56: 269-273. http://dx.doi.org/10.1016/j.msec.2015.06.031

[20] Manoj, M.K., Galgali, R.K., Nath, S.K., Ray, S. (2008). Synthesis, characterization and effect of microstructure on slurry erosion resistance of cast Fe-TiC composites. Journal of Naval Architecture and Marine Engineering, 5(1): 19-26. https://doi.org/10.3329/jname.v5i1.1825

[21] Mahendra, K.V., Radhakrishna, K. (2007). Fabrication of $\mathrm{Al}-4.5 \% \mathrm{Cu}$ alloy with fly ash metal matrix composites and its characterization. Material Science Poland, 25(1): 57-68.

[22] Ramachandra, M., Radhakrishna, K. (2006). Sliding wear, slurry erosive wear, and corrosive wear of aluminium/SiC composite. Materials Science-Poland, 24(2): 333-349.

[23] Lindgren, M., Perolainen, J. (2014). Slurry pot investigation of the influence of erodant characteristics on the erosion resistance of titanium. Wear, 321: 64-69. http://dx.doi.org/10.1016/j.wear.2014.10.005

[24] Farahmand, P., Frosell, T., Mcgregor, M., Kovacevic, R. (2015). Comparative study of the slurry erosion behavior of laser cladded Ni-WC coating modified by nanocrystalline $\mathrm{WC}$ and $\mathrm{La}_{2} \mathrm{O}_{3}$. International Journal of Advanced Manufacturing Technology, 79: 1607-1621. https://doi.org/10.1007/s00170-015-6936-2

[25] Ren, Z.H., Jin, P., Cao, X.M., Zheng, Y.G., Zhang, J.S. (2015). Mechanical properties and slurry erosion resistance of SiC ceramic foam / epoxy co-continuous phase composite. Composites Science and Technology, 
107:

$129-136$

http://dx.doi.org/10.1016/j.compscitech.2014.12.012

[26] Akin, A., Ercenk, E., Yilmaz, S., Sen, U. (2011). Slurry erosion behaviors of basalt filled low density polyethylene composites. Materials and Design, 32(5): 3106-3111.

http://dx.doi.org/10.1016/j.matdes.2010.12.029

[27] Joshi, A.G., Kumar, M.P., Basavarajappa, S. (2014). Influence of $\mathrm{Al} 2 \mathrm{O} 3$ filler on slurry erosion behavior of glass/epoxy composites. Procedia Materials Science, 5: 863-872. http://dx.doi.org/10.1016/j.mspro.2014.07.372

[28] Xie, Y.S., Jiang, J.R., Tufa, K.Y., Yick, S. (2015). Wear resistance of materials used for slurry transport. Wear, 332-333: 1104-1110 https://doi.org/10.1016/j.wear.2015.01.005

[29] Levy, A.V., Crook, P. (1991). The erosion properties of alloys for the chemical processing industries. Wear, 151(2): 337-350. $\quad$ https://doi.org/10.1016/00431648(91)90260-2

[30] Sreenivasa Rao, K.V., Girisha, K.G., Rakesh, Y.D. (2016). Evaluation of slurry erosion wear characteristic of plasma sprayed $\mathrm{TiO}_{2}$ coated 410 steel. IOP Conference Series: Materials Science and Engineering, 149(1). https://doi.org/10.1088/1757-899X/149/1/012067 